\title{
SIMULASI KEAMANAN PARKIR PRIBADI BERBASIS MIKROKONTROLER dan ANDROID
}

\author{
Ahmadi \\ Fakultas Teknologi Informasi \\ Universitas Islam Kalimantan Muhammad Arsyad Al Banjari Banjarmasin \\ Email : ahmadifatek@gmail.com
}

\begin{abstract}
ABSTRAK
Monitoring suatu tempat parkir kendaraan umum bahkan kendaraan pribadi memerlukan perencanaan dan simulasi dalam proses pembuatan sistem ditempat parkir disebut baik digunakan sendiri bahkan parkir umum,bahkan memiliki alur dari aturan proses parkir kendaraan sampai posisi letak kendaraan itu sendiri bahkan bisa dimonitoring dari jarak jauh. Monitoring kendaraan pribadi adalah hal yang wajar dilakukan oleh prusahaan bahkan pemilik kendaraan sendiri, diperlukan suatu simulasi keamanan parkir berbasis android beserta proses parkir kendaraan dengan dipandu oleh sistem parkir itu sendiri. Dipenelitian ini Dibuatlah simulasi keamanan parkir berbasis android dan menggunakan inputan sensor ultrasonic dan LDR(Light Dependent Resistor), Sensor ultrasonic digunakan untuk inputan sistem yang digunakan sebagai inputan lampu pemandu dan buzzer pada sistem nantinya, sedang sensor light dependent resistor digunakan untuk indicator keberaan kendaraan ditempat parkir dan status kendaraan tersebut dikirim ke interface android sebagai penanda bahwa parkiran sedang kosong atau sudah diisi.
\end{abstract}

Keyword : Parkir Berbasis Adroid, Sensor Ultrasonik HC-SR04, sistem keamanan

\section{PENDAhULUAN}

Perkembangan teknologi dan informasi saat ini sangat pesat salah satunya dibidang transport. Alat transportasi kian hari kian murah dan terjangkau, mudahnya mendapatkan alat tersebut memicu naiknya jumlah pengguna alat transportasi, semakin meningkatnya vulume pengguna transport umum dan pribadi menimbulkan masalah baru, salah satunya tempat parkir pribadi.

Seiring dengan perkembangan teknologi banyaknya pengguna alat transportasi dewasa ini mulai kesulitan mencari lahan kosong untuk tempat parkir sehingga banyak pengguna kendaraan roda 4 memarkir kndaraanya di badan jalan dan tidak teratur. Semakin banyak jumlah penduduk yang ada di suatu daerah maka akan semakin memerlukan banyak lahan yang harus disediakan untuk tempat tinggal, hal tersebut membuat ukuran lahan semakin tahun semakin diperkecil. Keterbatasan lahan perumahan akan membuat semakin susuhnya membagi lahan tinggal dan lahan untuk space tempat parkir pada prumahan padat penduduk. Sempitnya lahan parkir pribadi menimbulkan banyak resiko kerusakan pada body mobil bahkan sampai kehilangan kendaraan pribadi akibat memarkir kendaraan sembangan di badan jalan maka dari itu perlu dibuatlah sebuah sistem "Simulasi Keamanan Parkir Pribadi Berbasis Android dan Mikrokontroler".

\section{METODE PENELITIAN}

Penelitian dilakukan dengan pengumpulan data, persiapan alamat, literature dan terakhir menguji sistem keamanan parkir pribadi berbesis android dan mikrokontroler antara lain:

\section{a. Tahapan Penelitian}

Penelitian ini dilakukan dengan beberapa tahapan antara lain :

1. Analisa Masalah, maslah yang akan diteliti adalah proses parkir yang 
memakan wakrtu lam dan kendala lahaun parkir yang sempit beserta sebagai keamanan saat mobil sedang berada didalm parkiran pribadi, sistem akan selalu mengecek kondisi parkir dan mengirimkan data ke smartphone pemilik/pengguna.

2. Mendesain alat/simulasi sistem yang akan dibagun dan mencoba hardware beserta sensor yang digunakan bahwa bekerja dengan baik dan sesuai dengan sistem parkir nantinya.

3. Merancang program disisi mikrokontroler sebagia proses utama dari sistem ini dan disisi android sebagai interface antar muka dengan pengguna kondisi parkir yang terisi atau kosong.

4. Menguji, memastikan alat di kedua sisi berjalan sesuai rencana yaitu disisi mikrokontroler adalah inputan dan output sensor ldr dan sensor ultrasonik, sedangkan disisi android akan dicek hasil perubahan dari posisi parkir jika bewarna merah maka parkir sedang digunakan dan warna biru parkir sedang kosong.

5. Menyimpulkan hasil dari penelitian ini dan membuat laporan dari setiap pengujian yang dilakukan pada kedua sisi hardware dan software.

b. Bahan bahan penelitan

Bahan-bahan yang digunakan dipenalitian ini adalah sebagai berikut:

1. Mikrokontroler adalah sebuah kendali utama dirangkaian elektronik yang digunaka sebagai otak dari sistem keamanan sistem parkir pribadi.

2. Arduino IDE digunakan sebagai editor menulis perintah, mengkompile dan mengunggah kode ke papan mikrokontroler,

3. Sensor ultrasonic adalah sensor yang digunakan untuk mengukur jarak antaran dinding dengan mobil yang akan parkir, yaitu dengan cara memancarkan gelombang ultrasonic dengan frekuensi $40 \mathrm{KHz}$.

4. Sensor rependen resistor adalah sensor yang digunakan sebagia inputan sistem, dengan cara mendeteksi perubahan cahaya di area parkir yang digunakan.

\section{HASIL DAN PEMBAHASAN}

\section{a. Pengujian Sensor Ultrasonic}

Pengujian untuk sensor Ultrasonik ini untuk mengetahui kemampuan sensor dalam mendeteksi jarak antara halangan atau benda yang berada di depan sensor. Pengujian dilakukan sebanyak 27 kali dengan posisi benda yang berbeda-beda. Jarak yang terukur oleh sensor akan ditampilkan ke monitor dibandingkan dengan jarak yang sebenarnya. Berikut hasil pengujian dari sensor untrasonik:

Tabel 1 Hasil Sensor Ultrasonik

\begin{tabular}{|c|c|}
\hline Jarak Sebenarnya & Tampilan Di \\
\hline 3 & 3,1 \\
\hline 4 & 4 \\
\hline 5 & 5 \\
\hline 6 & 6 \\
\hline 7 & 7,8 \\
\hline 8 & 8 \\
\hline 9 & 9,1 \\
\hline 10 & 10,5 \\
\hline 11 & 11 \\
\hline 12 & 11,9 \\
\hline 13 & 13 \\
\hline 14 & 14,2 \\
\hline 15 & 15,3 \\
\hline 16 & 16,1 \\
\hline 17 & 17 \\
\hline 18 & 18,3 \\
\hline 19 & 19 \\
\hline 20 & 20,1 \\
\hline 21 & 21,7 \\
\hline 22 & 22 \\
\hline 23 & 23 \\
\hline 24 & 24,4 \\
\hline 25 & 25 \\
\hline 30 & 30,3 \\
\hline 35 & 35,1 \\
\hline 40 & 40,1 \\
\hline
\end{tabular}




\begin{tabular}{|l|l|}
\hline 45 & 44,8 \\
\hline
\end{tabular}

Tabel di atas dapat disimpulkan bahwa kemampuan sensor Ultrasonik dalam mendeteksi halangan hingga sejauh $45 \mathrm{~cm}$ menghasilkan nilai yang hampir sama dengan pengukuran sebenarnya, meskipun dalam pengujian sensor ini sering terjadi error atau selisih pada jarakjarak tertentu.

\section{b. Pengujian Sensor Dependent Resistor}

Pengujian sensor LDR dilakukan untuk mengetahui kemampuan sensor dalam mendeteksi intensitas cahaya disekitar sensor dan ditempat parkir, pengujian dilakukan dengan menguji nilai intensitas cahaya yang telah ditentukan di mikrokontroler, berikut hasil pengujian :

Tabel 2 Hasil Sensor LDR

\begin{tabular}{|c|c|c|}
\hline Mikrokontroler & Serial & Tampilan \\
\hline \multirow[t]{6}{*}{$5-29$} & \multirow[t]{6}{*}{$\mathbf{O N}$} & 5 \\
\hline & & 10 \\
\hline & & 15 \\
\hline & & 20 \\
\hline & & 25 \\
\hline & & 29 \\
\hline \multirow[t]{8}{*}{$30-100$} & \multirow[t]{8}{*}{ OF } & 30 \\
\hline & & 35 \\
\hline & & 40 \\
\hline & & 45 \\
\hline & & 50 \\
\hline & & 55 \\
\hline & & 60 \\
\hline & & $>100$ \\
\hline
\end{tabular}

Disimpulkan bahwa logika yang ditanamkan pada mikrokontroler yaitu ada dua perintah yang akan dikirim ke komputer melalui serial monitor adalah sebagai berikut :

1. Jarak 5 sampai 29 sebagai sinyal ON

2 . Jarak 30 sampai diatas 100 sebagai sinyal $\mathrm{OFF}$

\section{c. Proses Masuk Mobil}

Proses mobil masuk dalam ruang (space) parkir. Input dari sistem parkir ini berupa jarak yang didapat dari sensor ultrasonik yaitu jarak, Sedangkan output dari berupa sinyal yang diteruskan ke buzzer dan ic 74hc595n diteruskan ke masing-masing led.

Setiap input mempunyai nilai keanggotaan direpresenatasikan dalam bentuk kurva segitiga dan trapesium. Operator "AND" digunakan untuk mengkombinasikan dan memodifikasi kedua input jarak dari sensor ultrasonik. Berikut membership function dari setiap inputan:

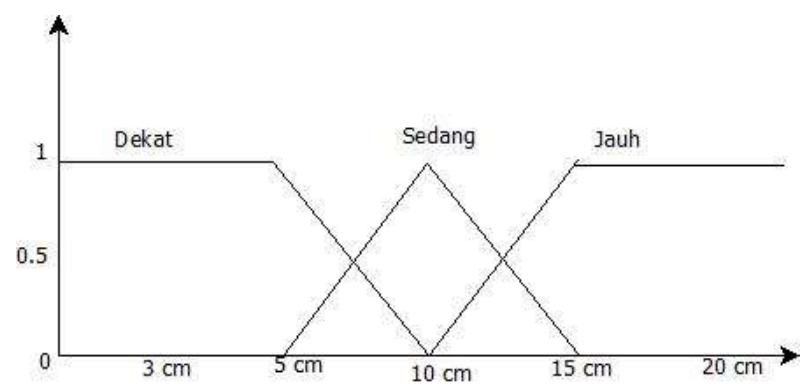

Gambar 1 Membership fuction Sensor Ultrasonik Keterangan :

Disimulasi Jarak sangat dekat dari dinding dengan mobil dari $0-15 \mathrm{~cm}$, sedangkan Jarak dekat dari diding dengan benda direpresentasikan dengan kurva segita dengan nilai $10 \mathrm{~cm}-20 \mathrm{~cm}$ dan Jarak jauh direpresentasikan dengan kurva trapesium yaitu nilai domain dari $15 \mathrm{~cm}$ hingga lebih dari $30 \mathrm{~cm}$.

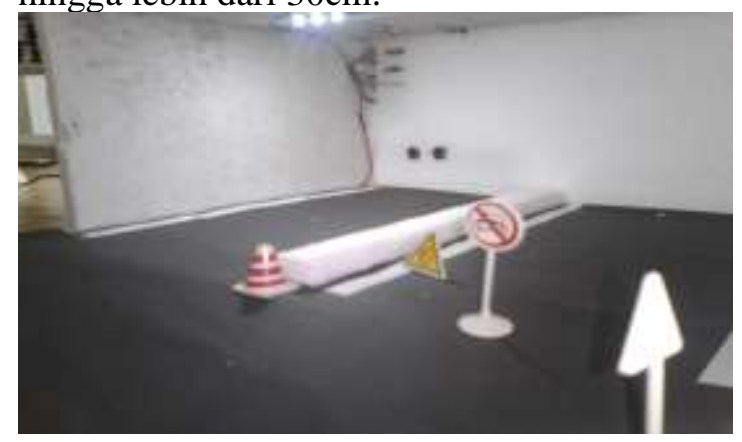

Gambar 2. Proses Parkir Jarak Sebelu Deteksi adanya Mobil yang Akan Parkir 


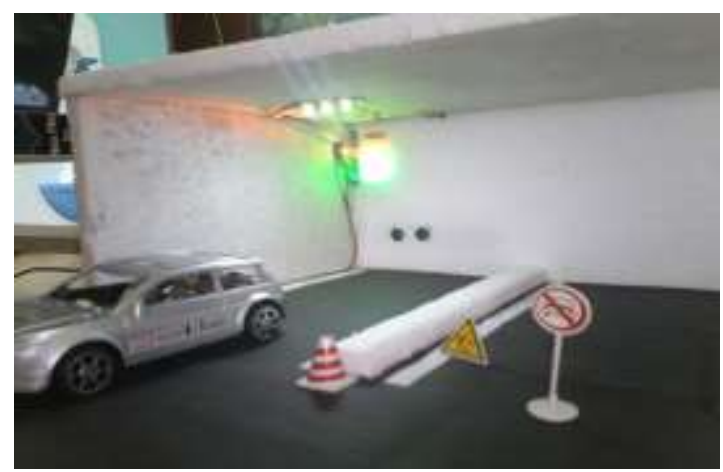

Gambar 3. Proses Parkir Jarak Jauh dari dinding

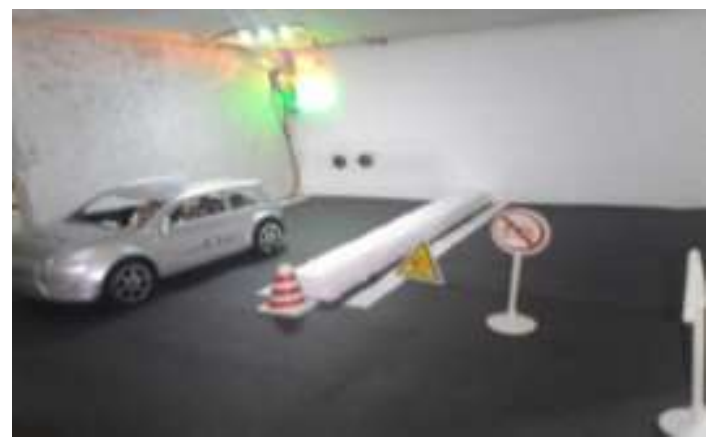

Gambar 4. Proses Parkir Jarang Sedang dari Dinding

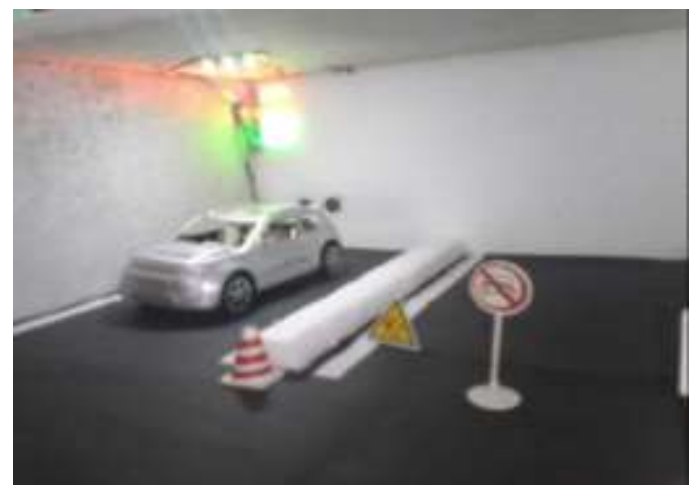

Gambar 5. Proses Parkir Jarak Dekat dari Dinding

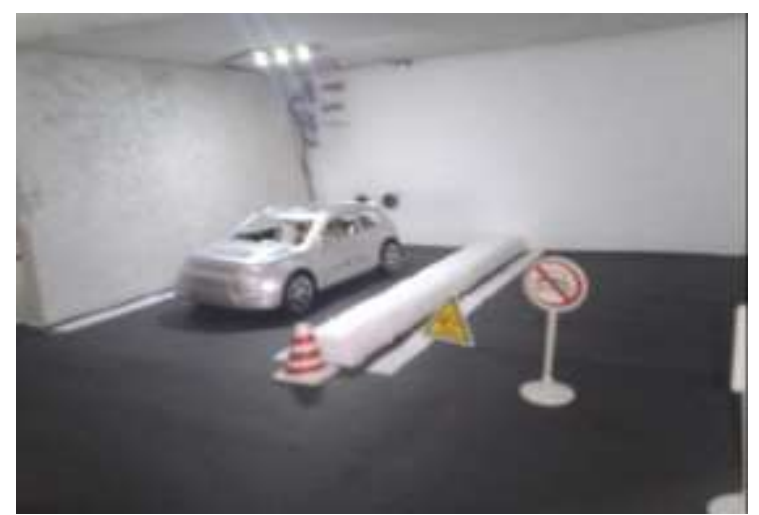

Gambar 6. Mobil Diposisi Parkir

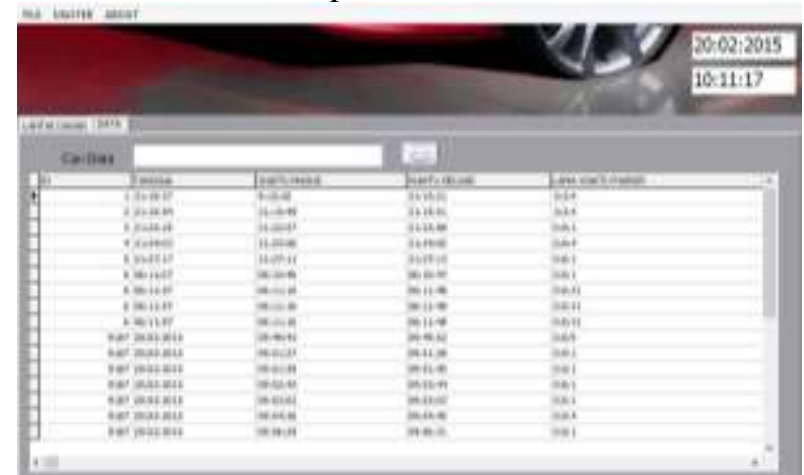

Gambar 7. Interface Parkir

\section{d. Hasil Monitoring disisi android}

Interface yang di rancang pada sisi program android ini digunakan untuk memastikan keadaan parkir yang sedang terisi dan keadaan kosong. Jika pada status berwarna biru maka parkir tersebut sedang kosong, apabila status berwarna merah maka parkiran sedang digunakan. 


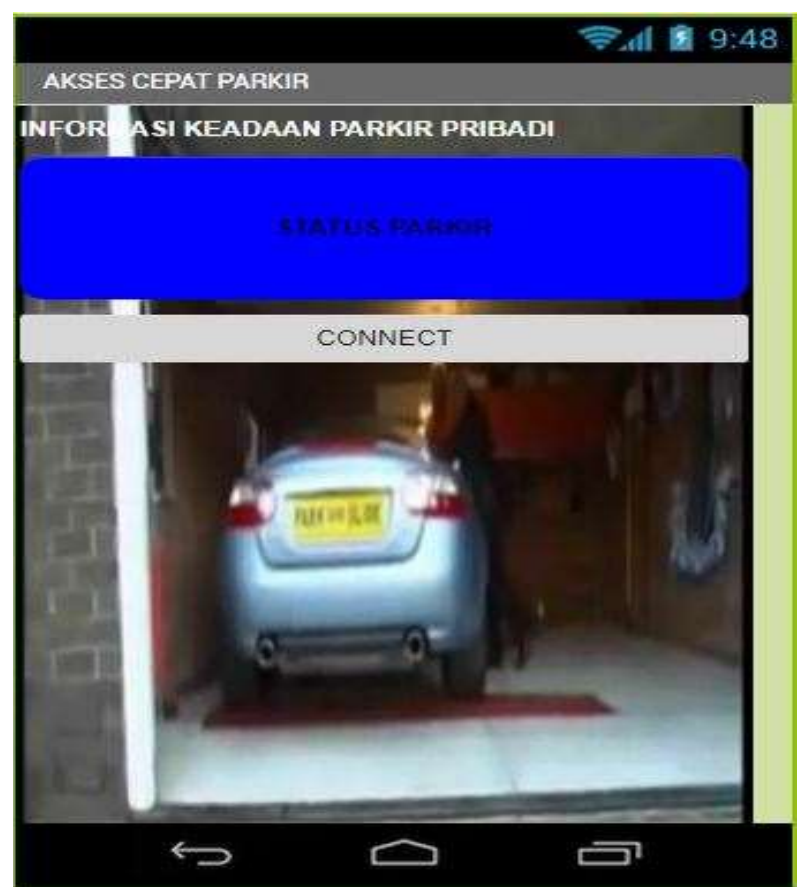

Gambar 8. Posisi Parkiran Normal

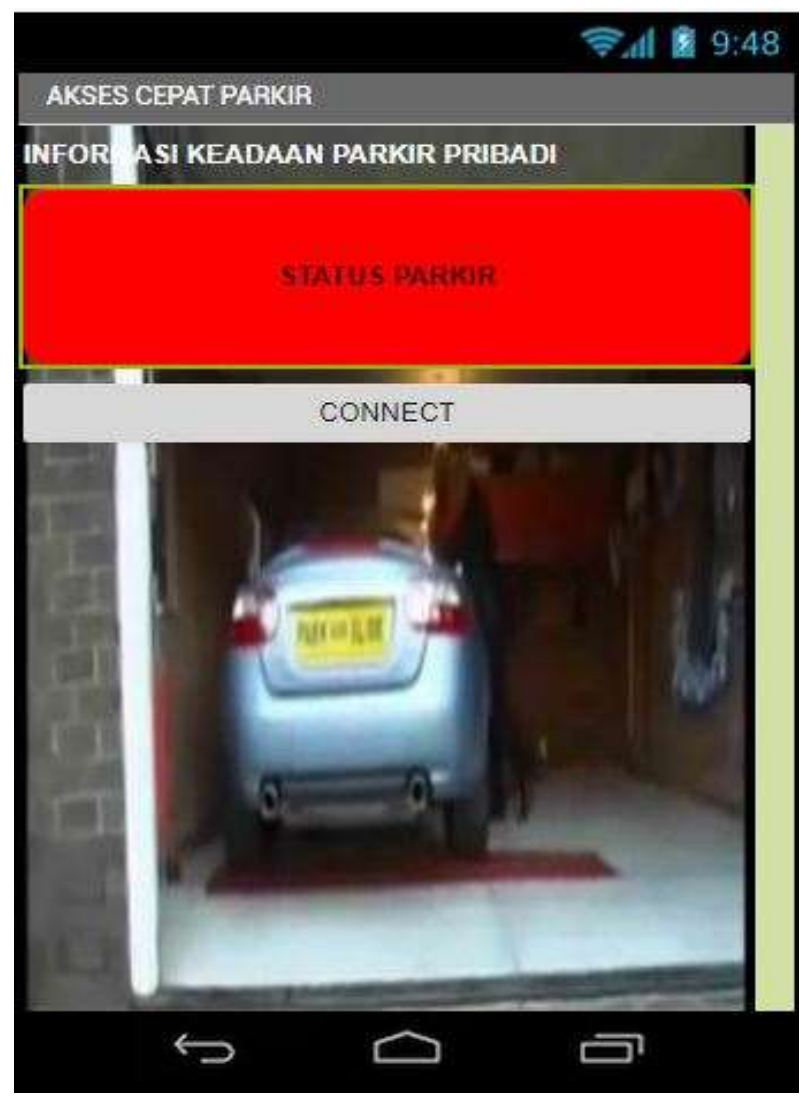

Gambar 9. Posisi Parkiran Sedang diguanakan

\section{KESIMPULAN}

Penerapan dan pemanfaatan simuasi sistem parkir dengan menggunakan arduino sebagai sentral utama dari simulasi sistem keamanan parkir pribadi, menerima inputan dari sensor ultrasonik sebagai pemandu pengguna untuk proses parkir dan inputan dari sensor ldr sebagai penanda posisi parkir normal dan penuh, Kesimpulan dari hasil simulasi parkir ini dapat menginformasikan jarak mobil dengan dinding sesuai dengan jarang sebenarnya, disisi interface android dapat menginformasikan konsisi parkir sedang dalam kondisi kosong atau sudah terisi. Simulasi ini membantu dalam informasi proses dan informasi parkir secara otomatis.

Dengan adanya sistem ini, maka pengguna parkir dapat tenang meninggalkan kendaraan pribadi dirumah untuk pergi berlibur keluar kota tanpa harus cemas memikirkan kendaraan kesayangan. Sehingga untuk implementasi di lingkungan yang berbeda perlu di lakukan kalibrasi ulang. Penggunaan sensor ldr dengan sumber cahaya yang tidak statis, tidak akan memberikan kondisi yang tepat pada tampilan visualisasi di layar monitor, Penggunaan led yang di tembakkan langsung ke sensor ldr bisa di jadikan solusi untuk mendapatkan hasil pembacaan yang lebih akurat.

\section{REFERENSI}

Ari Tri Overa.2014. Sistem Pemandu Kendaraan Untuk Parkir Paralel Secara Otomatis, yogyakarta.

Toni Supriatna.2013. Belajar Mudah Merangkai Rangkayan Elektronika, KATA PENA.

Ipan Irwanto.2013. Evaluasi Kinerja Arstiktur Kontrol Fuzzy Pada Simulasi Parkir Mobil Otomatis Menggunakan Labview, Yogyakarta.

Fahmi Aziz Nasruloh.2013. Perancangan Sistem Gedung Parkir Berbasis Mikrokontroler, Yogyakarta. 